\title{
LIFE CYCLES AND SECONDARY PRODUCTION OF EPHEMEROPTERA, PLECOPTERA, AND TRICHOPTERA (INSECTA) UNDER AN EXTREME CONTINENTAL CLIMATE (RIVER KHARAA, MONGOLIA)
}

\author{
Saulyegul A. ${ }^{1}$ \\ ${ }^{1}$ Institute of Geoecology, Mongolian Academy of Sciences \\ E-mail: saulegula@daad-alumni.de
}

\begin{abstract}
There are still knowledge gaps and uncertainties concerning the research of macroinvertebrates, in particular, a life cycle study of representative species are one such section of information missing in Mongolia. Therefore, this study was conducted within the framework of the biomonitoring program in the Kharaa River Basin under the research aims of the project entitled 'Integrated Water Resources Management (IWRM) in Central Asia: Model Region Mongolia (MoMo)'. This study provided the first quantitative results on the life cycle, production, growth rate and emergence of aquatic insects from Mongolia, to allow comparisons with studies in other regions using the same methods. The 3-year study (2007-2009) of the life cycles of eighteen selected species according to the larval body size distribution and emergence period showed that the life cycle strategies in Ephemeroptera, Plecoptera, and Trichoptera and their production in the Kharaa River Basin clearly indicated adaptations to the harsh environmental conditions with strict univoltinism and low secondary production. In conclusion, it is essential to obtain knowledge especially about life cycle strategies of macroinvertebrates to predict re-colonisation potential of disturbed habitats and to evaluate the efficiency of management measures.
\end{abstract}

Key words: larval development, emergence period univoltinism, secondary production, harsh climate

\section{INTRODUCTION}

Mongolia is a landlocked country, surrounded by high mountain ranges in the north and southwest and it is located in the transition zone between the great Siberian taiga and the Central Asian desert, which belongs to the central parts of the Eurasian continent (Nandintsetseg et al., 2007). Its climate is characterised by long, dry and cold winters (120-150 days with stable snow cover in the mountainous regions, about $85 \%$ of total precipitation falls from April to September and average air temperatures of $-15^{\circ} \mathrm{C}$ to -35 ${ }^{\circ} \mathrm{C}$ in January), and hot summers (average air temperatures of $15{ }^{\circ} \mathrm{C}$ to $25{ }^{\circ} \mathrm{C}$ in July), low precipitation (50 $\mathrm{mm}$ to $400 \mathrm{~mm}$ depending on the region) and a relatively high number of sunny days per year (260 $\mathrm{d} \mathrm{y}^{-1}$, average) for the years 1961 to 2001 (Batima et al., 2005; Nandintsetseg et al., 2007). The annual average temperature for Mongolia is $0.7^{\circ} \mathrm{C}$ (Batima et al., 2005), and $-0.4{ }^{\circ} \mathrm{C}$ in the study region of Kharaa river basin (Törnros \& Menzel, 2010). Major characteristics of extreme continental climates are long and cold winters with mean air temperatures below $0^{\circ} \mathrm{C}$ (Danks, 2007) with corresponding ice coverage of surface waters, which result in harsh environmental conditions for all aquatic life (Milner \& Petts, 
1994; Chambers et al., 2000). For instance, an important hydrological character of surface waters in Mongolia is the occurrence of an ice cover with a thickness of 0.8 to 3.2 meters for five to six months of the year and some rivers freeze into the bed (Batima et al., 2004). Depending on the species and besides habitat quality and food availability, general adaptations of aquatic insects to survive these conditions were described as a prolonged or staggered development and programmed life cycles with diapause, often resulting in strict univoltinism (Danks, 2007). However, synecological studies of aquatic insects in extreme cold continental climates and in particular Mongolian river systems are still limited (e.g., Hofmann et al., 2011; Maasri \& Gelhaus, 2011; 2012) the most recent studies

\section{MATERIAL AND METHODS}

The Kharaa River basin is located in Northern Mongolia, not far from the capital Ulaanbaatar, between latitudes $47^{\circ} 53^{\prime}$ and $49^{\circ} 38^{\prime} \mathrm{N}$ and longitudes $105^{\circ} 19^{\prime}$ and $107^{\circ} 22^{\prime}$ E. The catchment is $14,534 \mathrm{~km}^{2}$ and the main channel is $362 \mathrm{~km}$ long (Fig. 1a) and flows into the Orkhon River (catchment area 133,000 $\mathrm{km}^{2}$ ) which is a tributary of the Selenge River (459,000 km²) (MoMo Consortium, 2009). The Kharaa River basin is located in Northern Mongolia, not far from the capital Ulaanbaatar, between latitudes $47^{\circ} 53^{\prime}$ and $49^{\circ} 38^{\prime} \mathrm{N}$ and longitudes $105^{\circ} 19^{\prime}$ and $107^{\circ} 22^{\prime}$ E. The catchment is $14,534 \mathrm{~km}^{2}$ and the main channel is $362 \mathrm{~km}$ long (Fig. 1a) and flows into the Orkhon River (catchment area 133,000 $\mathrm{km}^{2}$ ) which is a tributary of the Selenge River $\left(459,000 \mathrm{~km}^{2}\right)$ (MoMo Consortium, 2009). A detailed description of the study region is given by Hofmann et al. (2011).

A total of seven sites were chosen along the main channel of the river in order to study the life cycle of the rivers macroinvertebrates have been focused on taxonomy and species diversity (Hayford, 2009; Purevdorj, 2009; Soldán et al., 2009; Judson \& Nelson, 2012). Therefore, there are still knowledge gaps and uncertainties concerning the life cycle study of representative macroinvertebrate species was one of these information holes.

The main hypothesis was to test whether or not EPT species in the Kharaa River have special adaptations to survive the harsh winter conditions in Mongolia and reduced secondary production. In order to proof these hypotheses, it was necessary to provide basic autecological information on the (i) larval and emergence densities, (ii) life cycle periods, and (iii) secondary production, growth rates of selected macroinvertebrate organisms.

(Fig. 1b). A principle for the selection of sampling points was to display the life cycle of species distributing in the upper, middle and downstream reaches of the basin.

Between 2007 and 2009, three projects were conducted in order to determine the life cycle period, secondary production and growth rate of important macroinvertebrate species from the EPT group. The structure of the material and method is presented in figure 2. Further sampling procedures, and detailed information can be found on the AQEM (2002), Haase et al. (2004) and Avlyush (2013).

Due to the location of the sampling sites, a similar temperature regime and a synchronised emergence period between years, large longitudinal differences in larval development within the basin were not expected. In order to enhance the validity of the results, data were pooled from all sampling sites, where the selected species were distributed, to create the life cycle development figures. 


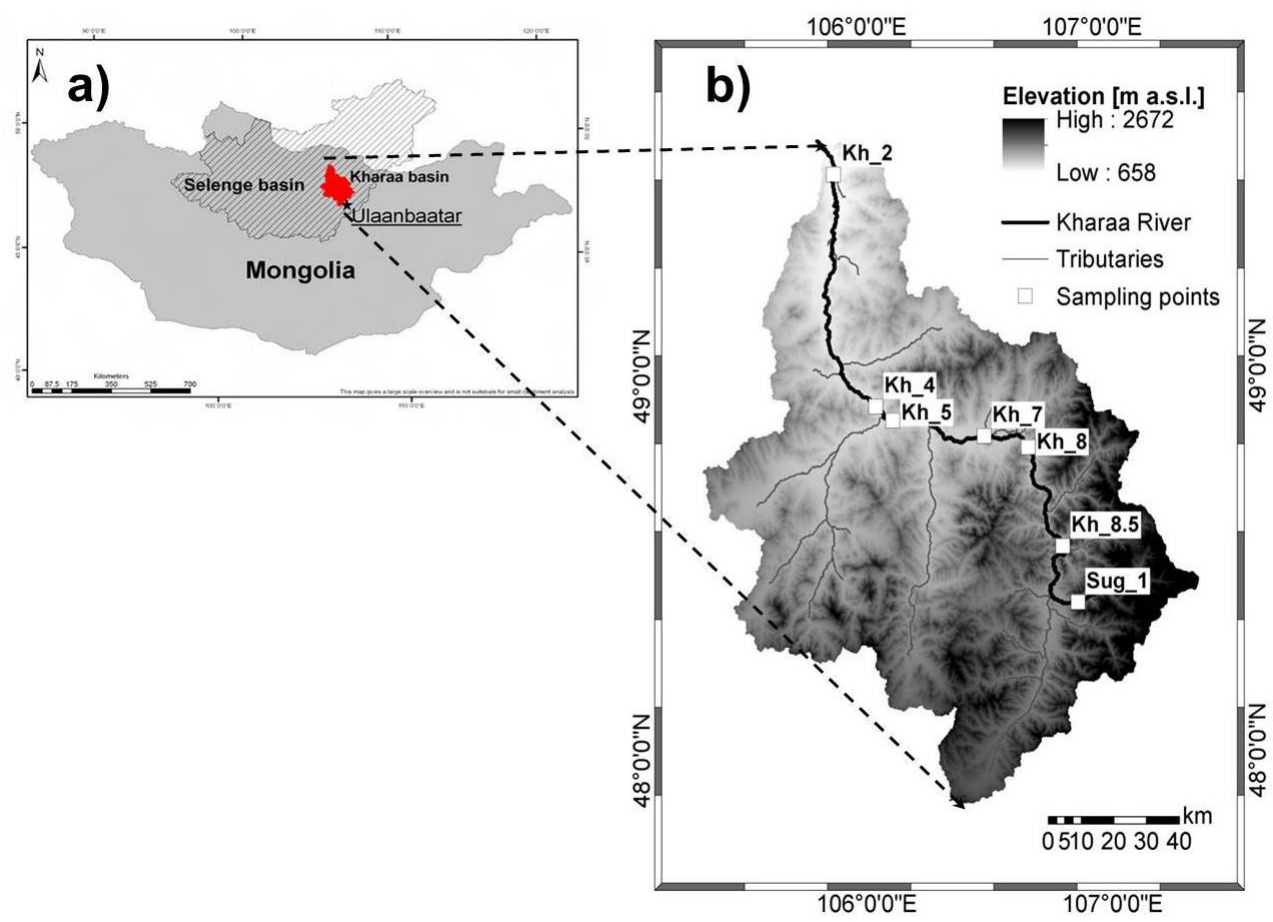

Fig. 1: a) The Kharaa River Basin (in black) is shown as part of the Selenge River Catchment (striped) being the main source region for Lake Baikal (Source: Map from e.g., Hofmann et al. 2011); b) the sampling locations are given with the short names.

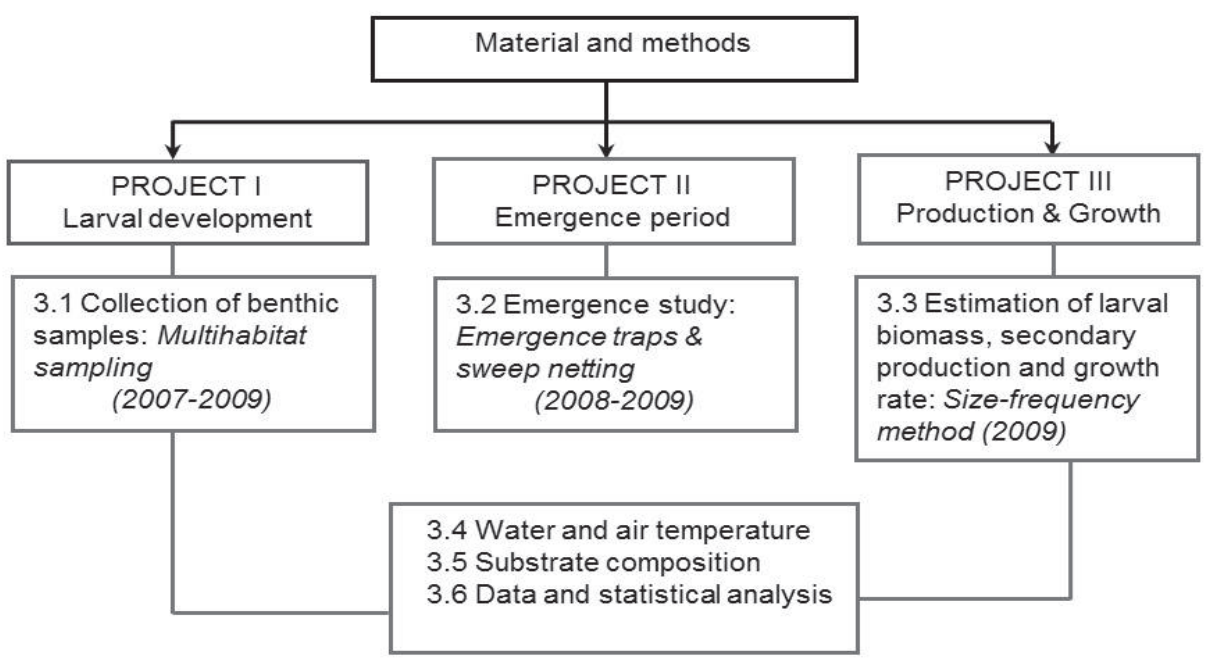

Fig. 2: A structure of sub-chapters identifying the sampling and estimation methods, abiotic measurements and data analysis. 


\section{RESULTS}

\section{Selection criteria}

A total of 140 EPT species consisting of 63 species of Ephemeroptera, 20 species of Plecoptera and 57 species of Trichoptera from 84 genera have been recorded in the benthic samples at seven sites $\left(\right.$ Sug_ $1 ; K h \_8.5 ; K h \_8$; $\left.K h \_7 ; K h \_5 ; K h \_4 ; K h \_2\right)$ along the Kharaa River during 2007 to 2009 (Schäffer, 2014; own data). In this sampling period and at these sites, the mean EPT larval density $( \pm S E)$ was $1867 \pm 145.5$ ind $\mathrm{m}^{-2}(n=77)$. Their mean biomass $( \pm S E)$ was estimated by $1.42 \pm 0.11$ g DW m ${ }^{-2}(n=77)$. A total of 43 EPT species including 12 species of Ephemeroptera, 8 species of Plecoptera, and 23 species of Trichoptera were recorded in the emergence traps at four sites (Sug_1; Kh_8.5; Kh_5; $\left.K h \_2\right)$ along the Kharaa River. The mean EPT emergence density $( \pm S E)$ was $23 \pm 3.0$ ind $\mathrm{m}^{-2}$ week $^{-1}(n=369)$ at three sites (Sug_1; Kh_8.5; Kh_5) in 2008 and 2009.

Five criteria were established to select the species for the life cycle study (Table $1 \&$ 2 ). The criteria 1,2 , and 5 are based on the quantity parameters or benthic density (ind $\mathrm{m}^{-2}$ ), biomass ( $\mathrm{mg} \mathrm{DW} \mathrm{m}^{-2}$ ) and emergence density (ind $\mathrm{m}^{-2}$ week ${ }^{-1}$ ). The results were displayed with the percentage of mean larval density of the selected species in the entire EPT groups from seven sites of the Kharaa River during 2007-2009. The criteria 3 and 5 are considered the most likely qualitative parameters or taxonomical determinability on the larval stages and the existence of literature data on life cycle and secondary production. Consequently, eighteen species including 8 species of Ephemeroptera, 3 species of Plecoptera and 7 species of Trichoptera were selected for inclusion in the study (Table $1 \&$ 2).

Life cycle and secondary production of only one species (Ephemera orientalis) within selected eighteen EPT species in the Kharaa River Basin are efficiently comparable to other regions (Table 2). A comparison on life cycle of selected 18 species with taxa from other regions at the genera level is considerably obtainable than information on secondary production (Table 2). Therefore, the criteria 5 displays the importance of this study providing the information on life cycle and secondary production of numerous species from EPT group under an extreme continental climate.

Table 1: CRITERIA 1 to CRITERIA 4 used to select the species from Ephemeroptera, Plecoptera and Trichoptera in the Kharaa River Basin for the life cycle and secondary production study.

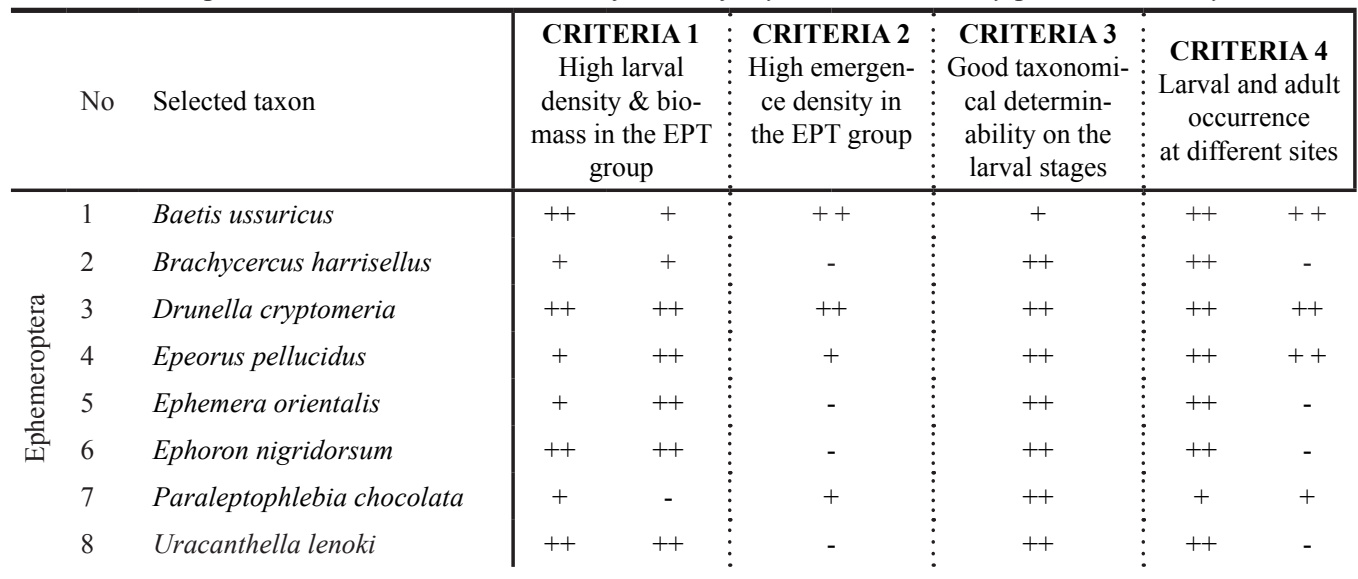




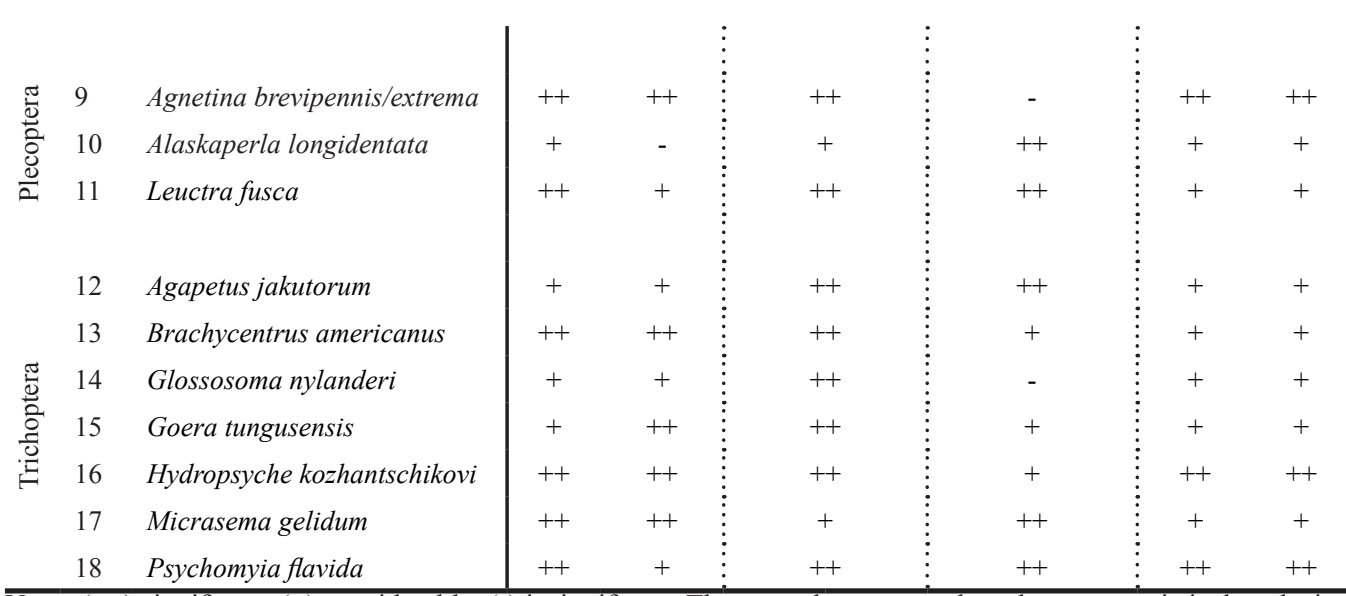

Note: $(++)$ significant; $(+)$ considerable; (-) insignificant. These results were not based on any statistical analysis.

Table 2: CRITERIA 5: The existence of literature data on life cycle and secondary production of selected species at the different taxonomical levels.

\begin{tabular}{|c|c|c|c|c|c|c|c|c|}
\hline & & \multirow[b]{2}{*}{ Taxon } & \multicolumn{3}{|c|}{ Life cycle } & \multicolumn{3}{|c|}{ Secondary production } \\
\hline & & & Family & Genera & Species & Family & Genera & Species \\
\hline \multirow{8}{*}{ 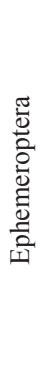 } & 1 & Baetis ussuricus & ++ & ++ & - & ++ & ++ & - \\
\hline & 2 & Brachycercus harrisellus & ++ & + & $+!$ & ++ & - & - \\
\hline & 3 & Drunella cryptomeria & ++ & + & $+!$ & ++ & - & - \\
\hline & 4 & Epeorus pellucidus & ++ & + & - & ++ & + & - \\
\hline & 5 & Ephemera orientalis & ++ & ++ & ++ & ++ & ++ & ++ \\
\hline & 6 & Ephoron nigridorsum & ++ & ++ & - & + & + & - \\
\hline & 7 & Paraleptophlebia chocolata & ++ & ++ & - & ++ & - & - \\
\hline & 8 & Uracanthella lenoki & ++ & + & - & ++ & - & - \\
\hline \multirow{3}{*}{$\begin{array}{l}\frac{\pi}{0} \\
\stackrel{0}{0} \\
\frac{0}{0} \\
\frac{0}{2}\end{array}$} & 9 & Agnetina brevipennis/extrema & ++ & + & - & + & - & - \\
\hline & 10 & Alaskaperla longidentata & ++ & - & - & + & - & - \\
\hline & 11 & Leuctra fusca & ++ & ++ & $+!$ & + & + & - \\
\hline \multirow{7}{*}{ 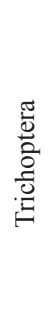 } & 12 & Agapetus jakutorum & ++ & ++ & - & ++ & ++ & - \\
\hline & 13 & Brachycentrus americanus & ++ & ++ & - & ++ & + & - \\
\hline & 14 & Glossosoma nylanderi & ++ & + & - & ++ & + & - \\
\hline & 15 & Goera tungusensis & + & + & - & - & - & - \\
\hline & 16 & Hydropsyche kozhantschikovi & ++ & ++ & - & ++ & ++ & - \\
\hline & 17 & Micrasema gelidum & ++ & - & - & ++ & - & - \\
\hline & 18 & Psychomyia flavida & + & - & - & - & - & - \\
\hline
\end{tabular}

Note: $(++)$ sufficient; $(+)$ existed, but very few; $(-)$ no existence; $(+!)$ existed, insufficient information. 


\section{Life cycle types}

Five different life cycle types in three major categories (univoltine, multivoltine, and semivoltine) have been identified for the eighteen selected species in the Kharaa River basin. The life cycle types were distinguished based on larval body size distribution and emergence period. Generally, the most abundant taxa in the Kharaa River have evolved strict univoltinism under the extreme climatic conditions $(78 \%$ of the discussed species). Univoltine life cycles were mostly evident in mayflies. About $33 \%$ or six out of the total selected species displayed a univoltine summer life cycle with hatching, growth and emergence taking place during the ice free period from May to October. Winter univoltine cycles are the most common life cycle type with $45 \%$ of the selected species (eight) showing this type of cycle. For this life cycle type individuals overwintered in the nymphal or egg stage. Caddisflies had the most representatives for the univoltine winter cycle. The remaining three life cycle types (seasonal univoltine, bivoltine, and semivoltine), two species from Ephemeroptera and one species from Plecoptera, and one species from Trichoptera were considered (Table 3).

Table 3: Life cycle categories of eighteen species from Ephemeroptera, Plecoptera, and Trichoptera in the Kharaa River Basin, Mongolia.

\begin{tabular}{|c|c|c|c|}
\hline Major category & Subcategory & Species & Order \\
\hline Univoltine & Us & Baetis ussuricus & Ephemeroptera \\
\hline Univoltine & Us & Brachycercus harrisellus & Ephemeroptera \\
\hline Univoltine & Us & Drunella cryptomeria & Ephemeroptera \\
\hline Univoltine & Us & Ephoron nigridorsum & Ephemeroptera \\
\hline Univoltine & Us & Leuctra fusca & Plecoptera \\
\hline Univoltine & Us & Agapetus jakutorum & Trichoptera \\
\hline Univoltine & Uw & Ephemera orientalis & Ephemeroptera \\
\hline Univoltine & Uw & Uracanthella lenoki & Ephemeroptera \\
\hline Univoltine & Uw & Alaskaperla longidentata & Plecoptera \\
\hline Univoltine & Uw & Brachycentrus americanus & Trichoptera \\
\hline Univoltine & Uw & Glossosoma nylanderi & Trichoptera \\
\hline Univoltine & Uw & Goera tungusensis & Trichoptera \\
\hline Univoltine & Uw & Micrasema gelidum & Trichoptera \\
\hline Univoltine & Uw & Psychomyia flavida & Trichoptera \\
\hline Univoltine & Us-Uw & Epeorus pellucidus & Ephemeroptera \\
\hline Univoltine & Us-Uw & Paraleptophlebia chocolata & Ephemeroptera \\
\hline Multivoltine & MBws & Hydropsyche kozhantschikovi & Trichoptera \\
\hline Semivoltine & $\mathrm{S}_{3 \mathrm{y}}$ & Agnetina brevipennis/extrema & Plecoptera \\
\hline
\end{tabular}

Note: Us-Univoltine, summer cycle; Uw- Univoltine, winter cycle; Us-Uw- Seasonal univoltine cycle (most of the new generation overwinters in the egg stage, and a small part of the population overwinters in the nymphal stage); MBws: Seasonal bivoltine winter-summer cycle (overwintering generation in the nymphal stage and one summer generation); $\mathbf{S}_{3 \mathbf{y}}$ - Seasonal semivoltine cycle with a generation time of about three years. 
To plot the length distribution showing life cycle development, two types of figures were created for 18 selected species. The life cycle development of Drunella cryptomeria (Ephemeroptera: Ephemerellidae) is presented as an example of the results on life cycle development. Detailed information for remaining 18 EPT species can be found on Avlyush (2013).

\section{Life cycle of Drunella cryptomeria (Ephemeroptera: Ephemerellidae)}

In total, 2,064 individual D. cryptomeria were sampled from the Kharaa River between 2007 and 2009. The body length of larvae ranged between $1.5 \mathrm{~mm}$ and $12.1 \mathrm{~mm}$. The earliest first instars were found in early May $\left(9^{\text {th }}\right.$ and $10^{\text {th }}$ of May, 2009) with a body length of 1.5 $\mathrm{mm}$ to $2.9 \mathrm{~mm}$. The mean body length $( \pm S E)$ was $2.2 \pm 0.03 \mathrm{~mm}(n=79)$. Therefore, it was concluded that eggs hatch around late April or early May. The nymphs exhibited very fast growth during May and June and the last instars first appeared at the end of June (Fig. 3a). The highest larvae density occurred between late May and early June (Fig. 3b). Emergence started from the beginning of June and ended by late August. The life cycle of mayfly $D$. cryptomeria showed a univoltine summer cycle with approximately an eight to nine month egg diapause. In total, 137 individuals of the last larval stage of D. cryptomeria were analysed and the sex ratio of 1:1 determined (females: males). The mean body length $( \pm S E)$ was $10.5 \pm 0.08 \mathrm{~mm}$ for females $(n=76)$ and $9.1 \pm 0.09 \mathrm{~mm}$ for males $(n=61)$. In total, 89 individuals of $D$. cryptomeria in the subimago and imago stages were analysed. The mean body length $( \pm S E)$ of $D$. cryptomeria was 6.7 $\pm 0.16 \mathrm{~mm}$ for females $(n=55)$ and $6.4 \pm 0.16$ $\mathrm{mm}$ for males $(n=34)$. The sex ratio was $2: 1$ (females: males).
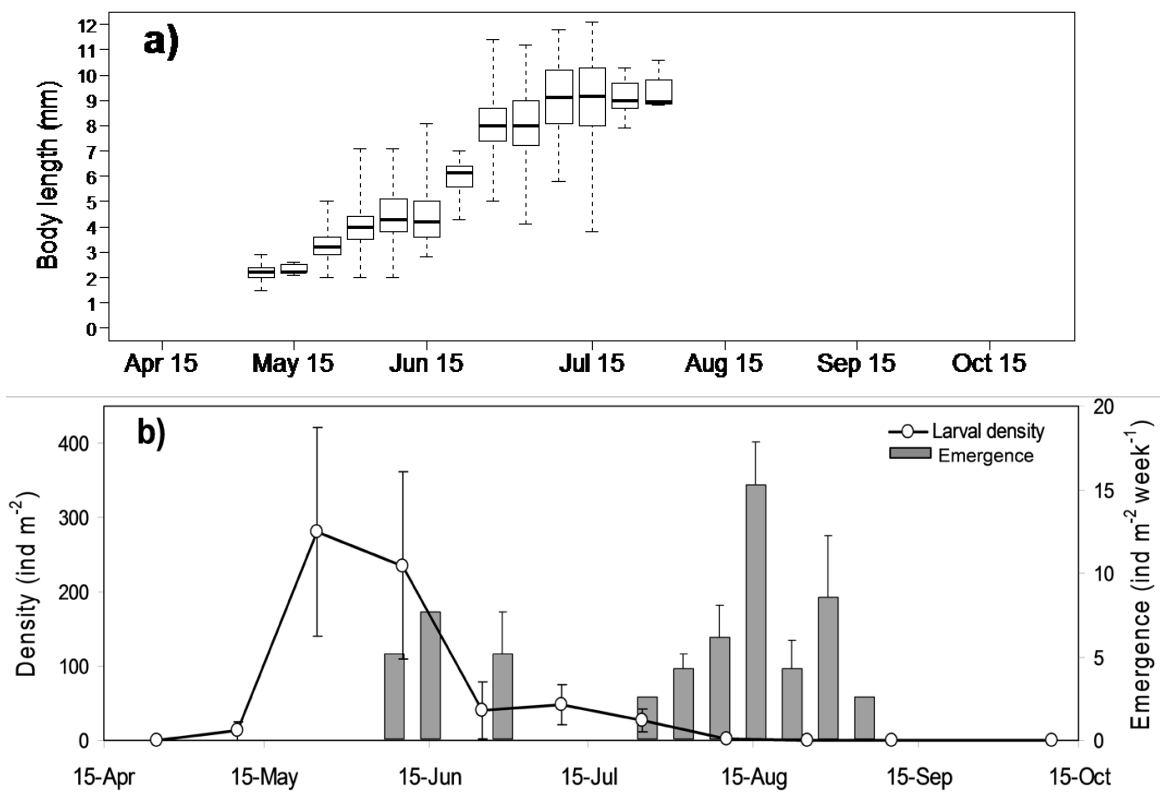

Fig. 3: The summarized results of D. cryptomeria (Ephemeroptera) during the ice free period in the years 2007 to 2009. a) Box-and-whisker plots (median, 25/75 percentile and 10/90 percentile) of larval body length $[\mathrm{mm}]$ and $\boldsymbol{b})$ Line and bar plots of larval [ind $\left.\mathrm{m}^{-2}\right]$ (mean $\left.\pm S E ; n=77\right)$ and emergence [ind $\mathrm{m}^{-2}$ week 1] (mean $\pm S E ; n=25)$ densities. 


\section{Secondary production and growth rate}

The annual secondary production values in 2009 were estimated for three sites in the Kharaa River (Sug_1; Kh 8.5; Kh 5) and were in the range $0.08 \mathrm{~g} \mathrm{DW} \mathrm{m}^{-2} \mathrm{y}^{-1}$ to 18.7 g DW m ${ }^{-2}$ year $^{-1}$. Over $85 \%$ of the total selected species contributed to the secondary production of less than $5 \mathrm{~g} \mathrm{DW} \mathrm{m}^{-2}$ year ${ }^{1}$. The remaining $15 \%$ or 3 species had annual productions of 5 to $10 \mathrm{~g}$ DW $\mathrm{m}^{-2}$ year ${ }^{-1}$ and one species had the annual production of above $15 \mathrm{~g} \mathrm{DW} \mathrm{m}^{-2}$ year $^{-1}$ (Fig. 4a). The frequency distribution of the annual $\mathrm{P} / \mathrm{B}$ rate was more heterogeneous compared to the distributions of the annual secondary production (Fig. 4b). The highest percentage of species had an annual $\mathrm{P} / \mathrm{B}$ rate of 5 year $^{-1}$ to 10 year $^{-1}$.

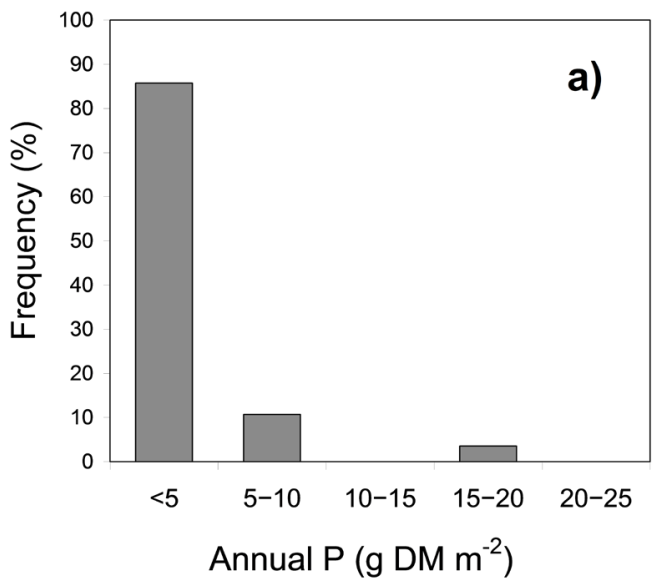

The mean daily growth $( \pm S E)$ of total univoltine summer cycle species was approximately 1.5 times higher $(0.039 \pm 0.007$ $\mathrm{mg}$ DW day $\left.{ }^{-1} ; n=65\right)$ than the total univoltine winter cycle species $(0.025 \pm 0.0046 \mathrm{mg} \mathrm{DW}$ day $\left.^{-1} ; n=85\right)$. The same result was estimated for growth rate. The total mean growth rate $( \pm S E)$ of the univoltine summer cycle species was about 1.4 times higher $(1.59 \pm 0.12 \%$ day $\left.^{-1}, n=65\right)$ than the total mean growth rate for the univoltine winter cycle species $(1.12 \pm$ $0.10 \%$ day $\left.^{-1} ; n=85\right)$. A high variation of daily growth among the species was obtained for both univoltine summer and winter species depending on their individual biomasses (Table 4).

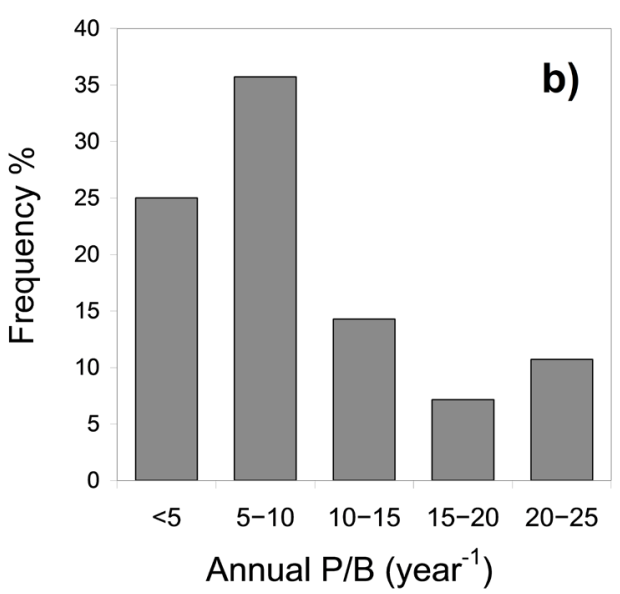

Fig. 4: Frequency distribution [\%] of a) annual secondary productions $(n=28)\left[\mathrm{g} \mathrm{DM} \mathrm{m^{-2 }}\right]$ and b) annual $P / B$ rates $(n=28)\left[y e a r^{-1}\right]$ for the selected species in the Kharaa River, 2009.

Two burrowing mayflies (Ephemera orientalis and Ephoron nigridorsum) with the highest individual biomasses demonstrated the highest maximum daily growths (Table 4). The highest mean growth rates were estimated for univoltine summer cycle species (Agapetus jakutorum and Drunella cryptomeria) with the shortest larval development time or days from hatching to final size (CPI: 70 to 90 days). The mean growth rates were similar among the winter cycle species. But, two species, Brachycentrus americanus and Psychomyia flavida, with the longest larval development periods (CPI: 310 to 330 days) showed the lowest growth rates (Table 4). 
Table 4: Daily growth (mg DW day-1; median, min, and max) and growth rate $\left(\%\right.$ day ${ }^{-1}$; median, min, and max) of univoltine summer and winter cycle species in the Kharaa River Basin in 2007-2009.

\begin{tabular}{|c|c|c|c|c|c|c|c|}
\hline \multirow[t]{2}{*}{ Species } & \multirow[b]{2}{*}{$n$} & \multicolumn{3}{|c|}{$\begin{array}{l}\text { Daily growth } \\
\left(m g \text { DW day }{ }^{-1}\right)\end{array}$} & \multicolumn{3}{|c|}{$\begin{array}{c}\text { Growth rate } \\
\left(\% \text { day }^{-1}\right)\end{array}$} \\
\hline & & Min & Median & Max & Min & Median & $\operatorname{Max}$ \\
\hline \multicolumn{8}{|l|}{ Univoltine summer cycle } \\
\hline Agapetus jakutorum & 4 & 0.0049 & 0.0136 & 0.0229 & 1.00 & 2.01 & 3.49 \\
\hline Baetis ussuricus & 22 & 0.0003 & 0.0026 & 0.0159 & 0.12 & 0.88 & 3.73 \\
\hline Brachycercus harrisellus & 11 & 0.0101 & 0.0166 & 0.0414 & 0.81 & 1.66 & 3.50 \\
\hline Drunella cryptomeria & 11 & 0.0071 & 0.0799 & 0.1407 & 1.42 & 2.18 & 3.60 \\
\hline Ephoron nigridorsum & 11 & 0.0100 & 0.1152 & 0.2334 & 0.09 & 1.62 & 2.71 \\
\hline Leuctra fusca & 6 & 0.0019 & 0.0053 & 0.0073 & 0.73 & 1.46 & 2.46 \\
\hline \multicolumn{8}{|l|}{ Univoltine winter cycle } \\
\hline Alaskaperla longidentata & 4 & 0.0005 & 0.0139 & 0.0438 & 0.15 & 1.13 & 2.50 \\
\hline Brachycentrus americanus & 18 & 0.0002 & 0.0019 & 0.0103 & 0.10 & 0.77 & 2.26 \\
\hline Ephemera orientalis & 14 & 0.0133 & 0.0604 & 0.3295 & 0.11 & 0.53 & 4.49 \\
\hline Glossosoma nylanderi & 12 & 0.0024 & 0.0138 & 0.0478 & 0.10 & 0.83 & 3.85 \\
\hline Goera tungusensis & 9 & 0.0070 & 0.0164 & 0.0527 & 0.21 & 0.89 & 2.80 \\
\hline Micrasema gelidum & 8 & 0.0031 & 0.0119 & 0.0287 & 0.13 & 1.42 & 3.41 \\
\hline Psychomyia flavida & 10 & 0.0004 & 0.0038 & 0.0132 & 0.07 & 0.72 & 1.98 \\
\hline Uracanthella lenoki & 10 & 0.0005 & 0.0032 & 0.0220 & 0.16 & 1.27 & 2.71 \\
\hline
\end{tabular}

\section{DISCUSSION}

Previous studies identified temperature as one of the main factors regulating the life cycle of aquatic insects (Vannote \& Sweeney, 1980; Newbold et al., 1994). Life cycle strategies in Ephemeroptera, Plecoptera, and Trichoptera and their production in the Kharaa River Basin clearly indicated adaptations to the harsh environmental conditions with strict univoltinism and low secondary production.

Under the extreme continental climate, abundant and representative species from the EPT group in the Kharaa River Basin group displayed a strictly univoltine cycle or completed their growth within a year (Fig. 5). Both univoltine summer and winter cycles were common. A diapause of egg stage for summer cycle species and larval diapause stage of winter cycle species during ice cover period cannot be confirmed with this study and remains as uncertainties for further studies.
There were eight species within 18 EPT species having a univoltine winter life cycle and these winter cycle species overwintered with a variety of larval instars. The questions of how they prepare for winter and which habitats they live in during winter were raised from this study after describing different life cycle types for further studies. There was a tendency of fast growth of those winter cycle species during autumn, or mature growth before the intense cold started. Considering the minimum air temperature of over $-40.0{ }^{\circ} \mathrm{C}$ in the basin and ice cover with a maximum thickness of $1.3 \mathrm{~m}$ (Batima et al., 2004), a long egg and larval stage with diapause would absolutely necessary. The flexibility of life cycles can be identified as extended life cycle stages in this region. The findings of short life cycle or seasonal bivoltine life cycle (one summer generation and one overwintering generation) 
and long life cycle or semivoltine life cycle identified for only one species suggest that the potential statement of water temperature change may occur in the Kharaa River Basin (Fig. 5).

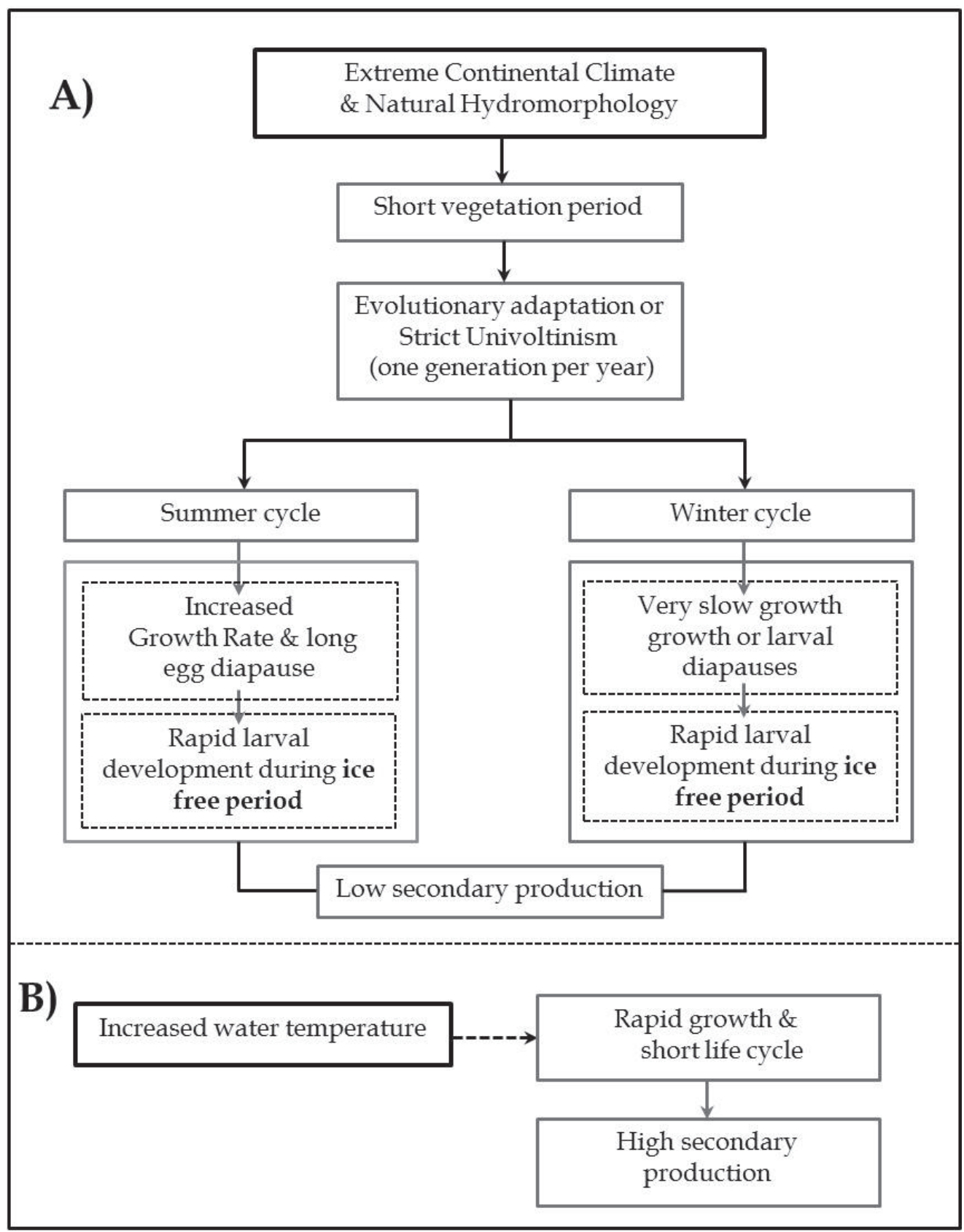

Fig. 5: The schema presents a) the main findings of life cycle of EPT species and secondary production in the Kharaa River Basin under an extreme continental climate and natural hydromorphology and $\boldsymbol{b})$ recognized temperature change, its impact on life cycle pattern and secondary production. 
Consequently, it is essential to compare the results with the general classification of growth of macroinvertebrates. Huryn and Wallace (2000) classified the low and high levels of production for macroinvertebrate communities in streams and rivers. Moreover, he also presented the classification of low and high growth rates of macroinvertebrate species with annual $\mathrm{P} / \mathrm{B}$ rate and daily growth rate. The results demonstrated that the Kharaa
River can be classified as a river with a low production (Table 6). In summary, the values of secondary production, annual $\mathrm{P} / \mathrm{B}$ rates and growth rates from the Kharaa River Basin are still comparable, but slightly lower than in other regions. The abundant species in the Kharaa River had a relatively rapid larval growth during short vegetation period and lower production which may be due to the extreme climatic conditions (Fig. 5).

Table 6: Secondary production (annual secondary production and annual $P / B$ rate) and growth rate comparison with the classification by Huryn and Wallace (2000). The results from Kharaa River Basin are given with percentage of total estimated values.

\begin{tabular}{|c|c|c|c|}
\hline Parameters & Classification & Range & Kharaa River Basin \\
\hline \multirow[t]{2}{*}{ Secondary production } & Low production & Up to $5.4 \mathrm{~g} \mathrm{DW} \mathrm{m}^{-2} \mathrm{y}^{-1}$ & $\approx 90 \%$ of total estimation \\
\hline & High production & From $121.0 \mathrm{~g} \mathrm{DW} \mathrm{m}^{-2} \mathrm{y}^{-1}$ & - \\
\hline \multirow[t]{2}{*}{ Annual $\mathrm{P} / \mathrm{B}$ rate } & Low growth rate & Up to $5.1 \mathrm{y}^{-1}$ & $25 \%$ of total estimation \\
\hline & High growth rate & From $62.0 \mathrm{y}^{-1}$ & - \\
\hline \multirow[t]{2}{*}{ Growth rate } & Low growth rate & Up to $1.4 \%$ day $^{-1}$ & $\approx 55 \%$ of total estimation \\
\hline & High growth rate & From $17.0 \%$ day $^{-1}$ & - \\
\hline
\end{tabular}

In conclusion, this study provided the first quantitative results on the life cycle, production, growth rate and emergence of aquatic insects from Mongolia, to allow comparisons with studies in other regions using the same methods. However, it still needs more quantitative research of population dynamics for a wider range of species including fecundity, accurate development rates, mortality losses

\section{ACKNOWLEDGEMENTS}

The research described in this paper was performed within the 'Integrated Water Resources Management in Central Asia: Modelregion Mongolia' (IWRM-MoMo) funded by the German Ministry of Education and Research (BMBF Grant 0033L003A) under the "Research for Sustainability" Programme and supported by the German Academic Exchange Program-DAAD (A/07/99089). (e.g., due to predation), and food availability across environmental gradients of hydraulic conditions and substrate types. In particular, an intensive investigation on a smaller spatial scale is essential to be carried out. In order to quantify fecundity and development rates it is essential to develop new methods of sampling eggs and earliest instar larvae in the field and to conduct laboratory experiments.
I would like to thank Prof. Dietrich Borchardt, Michael Schaeffer, Ralf Ibisch, Andrew Kaus, Melanie Hartwig, Soninkhishig Nergui, and Rüdiger Wagner for their contributions and support in this project and Batchuluun, Ts., Natsagnyam, $\mathrm{N}$ as well as Mongolian students Batsaikhan, Chantuu, Erdenezul, Zoljargal, Nergui, Otgonchimeg, Oyunbat, Undarmaa, Undralbat for their help during the expeditions and laboratory analysis. 


\section{REFERENCES}

1. AQEM Consortium. (2002) Manual for the application of the AQEM system:A comprehensive method to assess European streams using benthic macroinvertebrates, developed for the purpose of the Water Framework Directive. EVK1-CT1999-00027, version 1.0.

2. Avlyush S. (2013) Life cycles and secondary production of Ephemeroptera, Plecoptera, and Trichoptera (Insecta) under an extreme continental climate (River Kharaa, Mongolia). $\mathrm{Ph} . \mathrm{D}$ thesis, Technical University of Dresden, Germany, 175 p. (http://www.qucosa.de/ recherche/frontdoor/?tx slubopus4frontend[id] $=13483$ )

3. Batima P., Batnasan N. \& Bolormaa B. (2004) Trends in river and lake ice in Mongolia. AIACC Working paper, 8, 1-12.

4. $\quad$ Batima P., Ganbaatar D., Tumurbaatar D., Erdenetsetseg B., Bolortsetseg B., Gantsetseg B., Sanjid G. \& Khudulmur S. (2005) Climate change impacts on environment. In Climate change impacts, Batima P. \& Bayasgalan B. (Eds), Admon Publishing, Ulaanbaatar, 59-115.

5. Chambers P. A., Brown S., Culp J. M., Lowell R. B. \& Pietroniro A. (2000) Dissolved oxygen decline in ice-covered rivers of northern Alberta and its effects on aquatic biota. Journal of Aquatic Ecosystem Stress and Recovery, 8, 27-38.

6. Danks H. V. (2007) How aquatic insects live in cold climates. The Canadian Entomologist, 139, 443-471.

7. Haase P., Lohse S., Pauls S., Schindehutte K., Sundermann A., Rolauffs P. \& Hering D. (2004) Assessing streams in Germany with benthic invertebrates: development of a practical standardized protocol for macroinvertebrate sampling and sorting. Limnologica, 34, 349365.

8. Hayford B. (2009) First records of Podonominae (Diptera: Chironomidae) from outer Mongolia, with notes on ecology and biogeographic distribution. Journal of the Kansas Entomological Society, 82, 305-310.

9. Hofmann J., Hürdler J., Ibisch R., Schaeffer M. \& Borchardt D. (2011) Analysis of recent nutrient emission pathways, resulting surface water quality and ecological impacts under extreme continental climate: The Kharaa River Basin (Mongolia). International review of Hydrobiology, 96, 484-519

10. Huryn A. D. \& Wallace J. B. (2000) Life history and production of stream insects. Annual Review of Entomology, 45, 83-100.

11. Judson S. W. \& Nelson C. R. (2012) A guide to Mongolian Stoneflies (Insecta: Plecoptera). Zootaxa, 3541, 1-118.

12. Maasri A. \& Gelhaus J. (2011) The new era of the livestock production in Mongolia: Consequences on streams of the Great Lakes Depression. Science of the Total Environment, 409, 4841-4846.

13. Maasri A. \& Gelhaus J. (2012) Stream invertebrate communities of Mongolia: current structure and expected changes due to climate change. Aquatic Biosystems, 8:18.

14. Milner A. M. \& Petts G. E. (1994) Glacial rivers: physical habitat and ecology. Freshwater Biology, 32, 295-307.

15. MoMo Consortium. (2009a) Integrated Water Resources Management for Central Asia: Model Region Mongolia (MoMo): Case study in the Kharaa River Basin. Final Project Report, $201 \mathrm{p}$.

16. Nandintsetseg B., Greene J. S. \& Goulden C. E. (2007) Trends in extreme daily precipitation and temperature near Lake Hövsgöl, Mongolia. International Journal of Climatology, 27, 341-347.

17. Newbold J. D., Sweeney B. W. \& Vannote R. L. (1994) A model for seasonal synchrony in stream mayflies. Journal of the North American Benthological Society, 13, 3-18.

18. Purevdorj S. (2009) Updated species list of stoneflies (Plecoptera) of Mongolia. Aquatic insects, 31, 707-720.

19. Schäffer M. (2014) Strukturelle, funktionelle und physiologische Analyse der Makrozoobenthos-Gemeinschaften im Flussgebiet des Kharaa (Mongolei) unter Berücksichtigung von natürlichen und anthropogenen Umweltgradienten. Dissertation, Technical University of Dresden. In prep.

20. Soldán T., Enkhtaivan S. \& Godunko R. J. (2009) A commented checklist of mayflies 
(Ephemeroptera) of Mongolia. Aquatic Insects, 31, 653-670.

21. Törnros T. \& Menzel L. (2010) Heading for knowledge in a data scarce river basin: Kharaa, Mongolia. Status and Perspectives of Hydrology in Small Basins, Proceedings of the Workshop held at Goslar-Hahnenklee, 336, 270-275.

22. Vannote R. L. \& Sweeney B. W. (1980) Geographic analysis of thermal equilibria: a conceptual model for evaluation the effect of natural and modified thermal regimes on aquatic insect communities. The American Naturalist, 115, 667-695. 